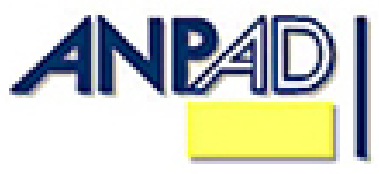

Available online at http://www.anpad.org.br/bar

BAR, Curitiba, v. 8, n. 1, art. 6, pp. 86-106, Jan./Mar. 2011

\title{
Social Practices and Strategizing: a Study of Produce Merchants in the Vila Rubim Market ${ }^{(1)}$
}

\author{
Alfredo Rodrigues Leite da Silva* \\ E-mail address: alfredoufes@gmail.com \\ Universidade Federal do Espírito Santo \\ Vitória, ES, Brazil. \\ Alexandre de Pádua Carrieri \\ E-mail address: aguiar.paduacarrieri@terra.com.br \\ Universidade Federal de Minas Gerais \\ Belo Horizonte, MG, Brazil. \\ Eloisio Moulin de Souza \\ Email address: eloisiomoulin@gmail.com \\ Universidade Federal do Espírito Santo \\ Vitória, ES, Brazil.
}

* Corresponding author: Alfredo Rodrigues Leite da Silva

Avenida Fernando Ferrari, 514, Goiabeiras, Vitória, ES, 29075-91, Brazil. Phone: + 552740092599

Copyright (C) 2011 Brazilian Administration Review. All rights reserved, including rights for translation. Parts of this work may be quoted without prior knowledge on the condition that the source is identified. 


\begin{abstract}
The aim of this article is to understand the relationship between the meanings of social practices and strategy creation used by the produce merchants in Vila Rubim, Vitória, ES, from 1970 to the present time. To provide empirical evidence of the conceptual framework that was developed, we conducted a case study. The data gathered from the documents and interviews were treated using discourse analysis, and those obtained from observations were treated using content analysis. The possibility and the act of approaching the neighboring merchant's customer is the link that joins the homonymous strategy and tactic, but the process in each of them has different implications (strengthening or transgressing the established order) and develops in different and dynamic ways. Thus, the denomination of strategies and practices is dynamic, relational and temporary because the focus is on the process that permeates each strategy and its articulations in the practices and meanings in each flow. In their socio-historic process, the produce merchants in the VR Market articulate various flows. Among them, the empirical investigation identified fourteen flows, nine as strategies and five as tactics, according to the social references assumed in the analysis.
\end{abstract}

Key words: making strategy; strategizing; social practice. 


\section{Introduction}

This article is a case study regarding produce merchants in a market and its goal is to understand the relationship between the social practices and strategy creation of the produce merchants in Vila Rubim's market in Vitória, ES, from 1970 to the present time.

This objective is connected with two basic concerns related with the strategy study as a social practice: (a) to present an approach to deal with the endless delimitations between the micro and macro levels of the strategy analysis as a social practice; (b) this approach bypasses the instrumental logic which predominates this field. Jarzabkowski (2005) acknowledges that, in the strategy study as a social practice, the practices are tools and artifacts which people use to make the strategy work. These practices take various forms: (a) influential use; (b) rational practice - strategic planning; (c) discursive practice - cognitive sources or the day-to-day interaction related to everyday language use and (d) opportunity practices - practitioners' interaction (meetings, courses). There are studies which focus management studies in a functional logic in the sense of instrumentalizing these practices (Ezzamel \& Willmott, 2004). With recognition of the relevance of the focus on the social practices, this article follows the same reasoning as the question raised. However, it refrains from instrumental logic and attempts to clarify how to establish the construction dynamic of the strategizing of everyday movements.

To deal with this dynamism, we quote the study of the analysis which Certeau (1990) made regarding the strategic rationalization. The author states that

as in Business Administration, all the strategic rationalization seeks first to distinguish the 'environment' and one 'very own', that is, the place of power, personal desire. Cartesian gesture, perhaps: circumscribe himself in a world bewitched by the invisible power of the Other (Certeau, 1990, p. 59).

It has to be clear that the author is not referring only to the organizations but to the strategies and everyday tactics of people in society as a whole, in which organizations are also included. One example is in the II volume of his book The Practice of Everyday Life, of which two members of his circle are co-authors, Luce Giard and Pierre Mayol. The latter, in the first part of this publication (Certeau, Giard, \& Mayol, 1994), when discussing the art of living, analyses the case of a merchant in the area of Croix-Rousse market in Lyon (France).

The strategic rationale of the privileged place of that very own in the war cited by Certeau (1990) or the typical strategy to focus, commonly found in studies of strategy as a social practice, shares space with a production that is characterized by what the author highlights as being clever tactics, in the underprivileged area of the other. As an example, a French market in an area in Lyon showed that the rationality of the strategies in sales are spread in the form of the deceitfulness of the merchant to steal from its trade in favor of and in collaboration with some special clients (Certeau et al., 1994).

By adopting the relationship between strategies and everyday tactics in the study of strategizing, this article seeks to make room for the understanding of the social dynamics involved in this execution. The challenge of strategy studies as a social practice highlighted by Wilson and Jarzabkowski (2004) remains: properly defining the limits of micro and macro levels will be discussed in the analysis, called relational distance. As a simple solution, the authors propose a prior outline of these limits in accordance with the object under study.

To deal with this question, the contributions of the Social Representations Theory (SRT) proposed by Moscovici (1961) were adopted. According to Certeau (1986), Moscovici’s contributions reveal processes related to the social practices that go beyond the construction of the normalizations institutionalized in society. In this article, it is emphasized that by doing so, Moscovici (1961) placed the Social Representations (SR) as a dynamic construction of the subjects themselves, and this is 
compatible with the idea that such tactics violate the institutionalization that is the basis of rationalization. In addition, the recognition of the role of individuals in defining their SR, allows the substitution of the previous outline of the relational distance since there is the assumption that the subjects fit to express such a definition. This arises as the construction of a specific social representation and is established when the researcher must understand the process in which these limits are established within its own dynamic.

These theoretical links will be discussed below and applied in the case study regarding strategizing of the produce merchants in the Vila Rubim market.

\section{Strategy as a Social Practice}

The contributions of authors such as Pettigrew (1977) and Mintzberg (1978) take the approach of the strategy as a process, concerned with investigating how strategy works in organizations. Based on these contributions, other authors developed the vision of strategy as a social practice. In this approach, the research focus on implementing the strategy within the organization considers "the skilled ability to use, adapt and manipulate those resources that are to engage in shaping the activity of the strategy over time” (Jarzabkowski, 2005, p. 34).

The concerns over implementing strategy in organizations have to do with "the detailed processes and practices that constitute the day-to-day activities of organizational life and relate to strategic outcomes" (Johnson, Melin, \& Whittington, 2003, p. 3). Therefore, there is a need to discuss the level to be taken in the analyses of those detailed processes and practices and, consequently, of implementing the strategy in the organization. Wilson and Jarzabkowski (2004) showed that without this delimitation, the researcher faces innumerous practices among the organizational players: each view or sound may be included on the edge of the micro level. Furthermore, the influences on this level can be extended, at the macrosocial level to any influence from a wide variety of places all over the planet.

Wilson and Jarzabkowski (2004) suggested the micro level should be defined according to the researched object and by what constitutes the macro level in the situation. This proposal takes the understanding that when we analyze these two aspects, the researcher should define the delimitations $a$ priori. However, this article disagrees with this option since it defines the relational distance in the initial methodological definitions according to the object under study. It is understood that the definition a priori would already exclude one of the subjects' main contributions concerning their research regarding their social practices: to state what surrounds everyday life.

As an alternative, we propose a path which emphasizes the dynamism of social construction and the role of the subjects to express the limits that involve their own connections in strategizing. In other words, if one defends the theoretical- methodological approach in which it falls to the subjects to indicate the outline between the micro and macro social levels, the construction surrounding strategizing in everyday social practice must be emphasized.

Apart from this, this paper departs from most of the work regarding strategy as a social practice because it does not focus on the upper management which is considered the basis of "strategizing" (e.g. Jarzabkowski, 2005; Jarzabkowski \& Wilson, 2002; Regnér, 2003; Samra-Fredericks, 2003; Whittington, 1996, 2003).

In the classical approach, the privileged holders of power in the strategic power mechanisms formulated the strategy so that the other actors would implement: a mind and body with each of them doing their part (Clegg, Carter, \& Kornberger, 2004). Even though they reject this understanding and defend an integrated view, the supporters of the strategy as a practice kept the role of strategizing focused on top management. The authors only included the influence of the practices for the remaining actors in the process. Now there are two minds, one with a stronger power than the other, and the 
body. The mind with the weaker power is responsible for the body and for influencing the other mind responsible for strategizing. A common argument in the studies is the affirmation that the asymmetry of power favors top management. Therefore, it would be interesting to focus on it (Jarzabkowski, 2005); this reinforces the idea of separation between body and mind that is hidden in an integrated discourse which criticizes and at the same time reinforces.

Another aspect to be criticized, agreeing with Ezzamel and Willmott (2004), is the concern to identify the tools, techniques, and skills used in the everyday process to reveal the appropriate instrumental use of these elements which include an integrative culture. The study by Wilson and Jarzabkowski (2004) exemplifies this proposal when they discuss the possible inter-relationships between the organizational level and strategizing at a micro level and in cultural dimension. The authors' argument is based on the perception of the integrated culture in which certain training and socialization processes allow the dominant and desired logic to be developed and to have continuity.

Therefore, it highlights some practical emphasis in which it would be possible to offer tools for upper management to better deal with strategizing, and it also explains the fact that a good deal of studies are focused at this level. This emphasis is not the basis of the approaches but it is present in the group with influence in various approaches of social theory in which the authors connect contributions of Foucault (1987), Giddens (1984), Bourdieu (1990) and Certeau (1990), among others (Wilson \& Jarzabkowski, 2004).

Despite the criticism, this connection and concern with practices when strategizing is explored leads to the inclusion of this work in this approach. This inclusion comes from the understanding that no criticism presented here eliminates the legitimacy of the approach, nor can the entire field be generalized. They only expose some aspect present in the field and opposite the lines of arguments proposed in this paper which should be circumvented when adopting the contributions of this approach.

In this paper, these contributions are directed at highlighting the relationships which involve the practices of the organizational actors as a whole, recognizing their different contextual inclusions. It is assumed that the strategies in and of the organization only exist from the social practices and complex interaction, making this paper responsible for the challenge of highlighting existing relationships in this process and thus, legitimizing this understanding. This discussion will be developed below from the contributions of the SRT elaborated by Moscovici (1961).

\section{Social Representations (SR) and Strategy Study as Social Practices}

There is a close relationship between everyday practices and representations (Vergès, 1989). The former enable the elucidation of social interaction processes whereas the latter are built and used (Jodelet, 1989). It justifies, in this essay, the use of a concept of SR which highlights this knowledge Jodelet's (1989, p. 36) "it is a way of knowledge, socially elaborated and shared with a practical goal that contributes to building up a reality common to a social group”.

According to Jodelet (1989), the usage of this description must respect the understanding that the SR are from the subjects over the objects. This understanding is interpreted as a need to define both of them a priori. But, when the subjects are already defined, it is possible to allow them to indicate the objects and the SR that associate and articulate in some contexts. Offering the epistemological basis to deal with this contextual insertion, the SRT offers important contributions to the strategic approach as social practices. As Jarzabkowski (2005) states, the social practices must be put in a context to highlight what led the subjects to articulate them, as well as their implications.

The SRT focus on the process of maintenance, change and the appearance of some social practices associated to the subjects' SR. Moscovici (1984) highlights that this happens through an anchoring and objectification process. According to the author, anchoring "strives to anchor strange 
ideas, to reduce them to ordinary categories and images, to set them in a familiar context" (Moscovici, 1984, p. 29), so that a religious person uses religious value scales to confront something new. Objectification "turns something abstract into something concrete, to transfer what is in the mind to something existing in the physical world”, such as religious statues (Moscovici, 1984, p. 29).

The subjects' social practices reflect this social constitution as a whole. However, the question remains as to how they develop interactions with implications positioned in certain groups composed of subjects that are commonly included not in one social group but in many. These subjects have a certain awareness of the specific contexts of the groups with which they currently interact.

In the search to broaden the comprehension of this dialogical process, SRT researches, like Marková (2000) highlight two concepts interconnected with anchoring and objectification: the themata (Moscovici, 1993; Moscovici \& Vignaux, 1994) and the communicative genres (Moscovici \& Marková, 1998). Themata is defined by Liu (2006, p. 255) as "historically embedded presuppositions, culturally shared antinomies, and the deeper logic of social thought".

Liu (2003) explains that in a social representation a hegemonic face there exist the themata, as well as emancipated and controversial views. The term emancipated indicates the constitution within specific groups, emancipated in relation to the society as a whole and without entering in conflict with the hegemonic sharing of this society. The controversial term already applies to the open and explicit conflict in relation to the diverse aspects, which include hegemonic and emancipated views.

The application of the themata concept in the SRT is legitimized by the generative capacity of its themes. The themes considered as analysis units and accessed through methodologies of data collection are dialogically interdependent when referring to the themata. Liu (2006) explains that the first ones can be ephemeral, situational and do not constitute a way of becoming a duo or a trio. On the other hand, the themata are reasonably stable, built over time. "They are typically antithetical dyads such as atomicity/continuum or analysis/synthesis, but also, occasionally, apola-triads such as constancy/evolution/catastrophic change” (Liu, 2006, p. 254).

The contributions to the linguistic field by Bakhtin (1986) concerning discursive genres were allied by Moscovici (1993) to his concept of the communicative system. Marková (2000), explains that these systems mold the SR and are molded by them when incorporating the idea of genres, the so called communicative system legitimizes itself based on Bakhtin's contributions, reinforcing the idea that through them different questions can be emphasized or minimized through the use of specific terminologies and according to the practices and social groups of which they are part.

Bakhtin (1986, p. 87) explains that "genres correspond to typical situations of speech communication, typical themes and, consequently, to specific contacts between the meanings of words and actual concrete reality under certain typical circumstances”. The author explains that the selection of words to be used in the creation of any elocution is not made based on the neutrality of the linguistic system, but on previous elocutions, especially those that are familiar.

According to Marková (2000), the communicative genres and the SR are presented in dynamic or relatively stable compositions. In this sense, Rosa (2006) explains that the previous concrete (objects with stabilized senses), that served the objectification process, takes on new meanings (Rosa, 2006). In this process, the conflict between stability and dynamism reflects the ambiguity of the SR, associated with four different concepts presented in the following way (Marková 2000): (a) the formation of the themata is a characteristic of the genres; (b) as it happens, they serve as a basis for dealing with the unknown through the creation of SR that incorporate and articulate the unknown with the themata (the known); (c) this creation results from the anchoring and objectification process inserted in the communicative genres necessary to the symbolical changes that enable these processes and express the SR.

Based on the theoretical discussion, the argument of the strategy approach as social practices is defended and offers, from the elements incorporation of SRT, contributions that allow the development of the field. The challenge is to find support in the social theory that allows an 
understanding of the articulation process of the social practices in strategy implementation in the organization that must be compatible with the SRT approach, which was sought in the contributions of Certeau $(1986,1990)$.

\section{Contributions of Certeau to the Study of Strategy as a Social Practice}

Wilson and Jarzabkowski (2004), among other authors, have recognized in the contributions of Giddens (1984), Bourdieu (1990) and Certeau (1990) a concern for social practices and their possibilities of promoting structural changes, that is, offering pathways for the analysis of strategy as a social practice. In the cases of Giddens (1984) and Bourdieu (1990), there is greater emphasis on structural recursivity, from which standpoint practices are the basis for both maintaining tradition and the possibilities for change. In contrast, Certeau (1990) does not centralize his concerns on recursivity.

Certeau (1990) starts from the assumption that passive and disciplined users of ordinary everyday practices also relate to each other in an anti discipline, based on expedients in their everyday practices (ways of doing things). When this perspective is confronted with the discussion of strategizing in organizations, it allows moving beyond the instrumental rationality of the practices. This is achieved from the moment that the author's contributions offer a distinctive path for dealing with the fact that passivity and discipline contribute to the actuation of certain people in deliberate planning efforts; but there is also resistance within organizations which enables a certain level of transgression by actors.

To investigate this expediency, or making do, we apply what Certeau (1990) calls bricolage: the creative inventiveness or art of expediency associated with getting things done. This concept composes the base of tactics: a calculus that cannot count on a proper, or on a dividing line distinguishing the other as a visible totality. According to the author, this occurs because the making do dwells in the spaces for transgression that remain inserted in the place controlled by the other. It is in these spaces for expedients in the place controlled by the strong that the weak articulate to take advantage of outside forces through movements including everyday practices, such as speaking.

The place that permits differentiating the other is based on disciplinary procedures (Foucault, 1987) and enables what Certeau (1990) calls strategy. In the interplay between discipline and anti discipline, everyday strategies and tactics are present in all people's lives, including in organizations. Therefore, a common link that would permit investigating these everyday strategies and tactics would also enable the study of strategizing in organizations. This link is offered by Certeau (1990): they are practices, acting in places and spaces, in strategies and tactics, in discipline and anti discipline.

For the author, in strategies the practices take in consideration calculations for the relationships of strength with basis in an outlined place in the privileged himself. The term itself is used by the author, as in this work, to denote a place of power and differentiated need in an environment, i.e., an order established from a boundary beyond the disorder, the boundary itself; as well as the subjects positioned in a privileged manner in this order which acts converging to it and reinforcing it. This presents itself in a position of power to distinguish and manage stocks in an environment.

While the strategy may rely on the self who connects its practices, the tactic relies on the other, without that place of power. This other articulates into spaces of transgression in that place, while it uses elements of power as a bound which legitimizes the transgress spaces (Certeau, 1990). In relation to the organizational strategy concept, the way that Certeau (1990) deals with the art of inventing, connected with strategies and everyday tactics, raises a question regarding the focus of this creation to the organizational strategy. Rather than turning into organizational strategy, emphasizing the study of the strategies and everyday tactics of the people in the organizations which are included the practices related to the organizational strategies since they are also developed by the people in their everyday life. While the organizational strategies limit the organizational objectives, defined by the members of 
the organizations positioned in the place with the power to define these objectives, the strategies and everyday tactics in the organizations involve endless convergent and divergent interests with the organizations.

In this understanding, the practices in the strategies within organizations involve the conciliation of aspects such as interests, resources and results which is not necessarily presented in a manner coherent in itself since it does not deal with a rational instrumental logic but rather a social constitution inherent in the practices of the subjects in their experiences with other subjects. The conciliation inserted in the social contexts of these subjects, contexts which constrain the practices of these subjects and on the other hand, offer conditions so that they use time and space in their favor, to the point of changing that awkwardness during their own conciliation.

To embrace this process, it is proposed that strategies and tactics in organizations are understood as the composition of flows in the social practices inserted in the specific organizational contexts and broader social contexts. This understanding includes different flows in the organizations. Here are different types of strategies, from the organizations, such as the growth in the market by means of the reduction in costs, to the personal, such as a search for career advancement, or any other type of outline that revolves around specific goals within his place, considered as a reference by whoever analyses this composition. Between one strategy and another, only the emphasis in relation to the contextual integration of the subjects involved varies. None of these is isolated from the other social constitutions, they are only seeking an outline in the place of oneself which revolves around the practices and goals that indicate the specificity of the strategy in question. Likewise, the tactics are also included in this composition, but in flows in which the contextual insertion used as reference do not have a self privileged place. They arise from the connections utilized in this place to delimit an area that is violated by the subjects that assume directions that are non convergent to this area, and this is when the rationality gives way to deceit (Certeau, 1990).

Within this approach, Certeau's (1990) contributions allow us to understand the strategy creation in the organizations within the dynamic perspective, having as a reference the place of the SR itself based on the understanding of Moscovici (1961). As Certeau (1986) explains, it is a vision in which the representations are not limited to something static, streamlined and institutionalized; it relates to the dynamic of social practices. To find evidence the empirical application of the conceptual framework developed, we conducted a case study seeking to understand the relationship between the meaning of social practices and the directional flow of the ways of making strategy in selling fruit and vegetables in the VR market.

\section{The Empirical Investigation of Strategy Making in the VR Market}

The proposed conceptual scheme is based on an investigation whose unit of analysis is the social practice of the subjects (ways of selling, buying, bargaining, joking...). According to Jarzabkowski (2005), among other authors, these practices involve concerns of a qualitative nature. In other words, this approach offers depth to the investigation, but is more focused on the meanings and the complex human processes that permeate them (Denzin \& Lincoln, 2006).

The method adopted is configured as a case study. According to Yin (1989), the case study is featured as a research in which the object of the study is the unity which examines deeply and may be characterized as a detailed analysis in an environment, of a single subject or a specific situation. In the case of empirical research discussed in this paper, the trade in the produce market in Vila Rubim, Vitória, ES, was studied.

The choice of this locus, to outline this study in this area, is due to three aspects: (a) it is a unique organization that brings together public interest (city and state) and private interest (several retailers and suppliers with complementary or different activities) connected in a common area; (b) 
there is the social cultural importance that throughout the decades, it was inserted in a meaningful way in the everyday life in the city; and (c) there has been the direct impact of the restructuring of urban areas which results in the city center becoming a marginalized area and its establishments experience greater difficulty to survive. In the diverse activities of the market, the focus of this study was on the trade of the produce in general, the original activity in the market that has prevailed for years, reaching its height in the 1970s when there were more than 300 merchants. However, nowadays there are less than a dozen.

Due to the temporal outline of this route on the disappearance of the produce traders, this study was limited in time from the periods of 1970 to the present. That is, the focus of this study is in the comprehension of strategizing that have taken place since 1970 until today but it includes previous strategy creations, from traders who are no longer in the market, which were attributed to the relations with the strategies developed along the period established.

To carry out this investigation, we first made a preliminary observation at the market, together with gathering documents available in public archives. Then, in the main part of the study, we observed first by participating as customers, and then conducted interviews on the life stories of the people at the market. When necessary, we asked follow-up questions. In the case of some interviewees, we took more detailed life stories that required further interviews at a later date. In parallel with the interviews, we observed the daily routine of the produce merchants, based on the same interview script, and carried out a non-systematic observation at the houses of two customers, and on two occasions, one of us accompanied merchants in their bargaining to buy produce at the region's central wholesale market, CEASA, in another town.

We applied discourse analysis (DA) to the data from the interviews in order to delve deeper into the interdiscourse, in addition to the syntactic and semantic dimensions involving the meanings expressed in the intra discourse. The discourse is assumed here to be "the combinations of linguistic elements (sentences or groups of several sentences), used by speakers to explain their thoughts, to talk about their exterior or interior world, to act on the world” (Fiorin, 2003, p. 11). The semantic route and its subsets form the main descriptive category of intra discourse, bearing the world view advocated and organized, implicitly or explicitly, by means of themes and figures. The themes encompass abstract elements such as joy and betrayal, while the figures utilize elements of the natural world such as wife and house (Fiorin, 2003). These elements were identified by analyzing, in the oral and written texts, the following discursive persuasive strategies: construction of personalities, lexical selection, silence, relation between explicit and implicit elements.

Barry and Elmes (1997) identify the use of construction of personalities to highlight or conceal those (persons, organizations, etc.) related to determined themes. For Watson (1995), lexical selection defines the vocabulary of groups, and is used to refer to themes and figures. Mumby and Stohl (1991) stress the importance of the relationship between the said and unsaid (silencing), because this shows what is systematically remembered or forgotten. Furthermore, according to these authors, discursive practices are immersed in a system of explicit and implicit content relations. The explicit ones are evident when stated - the speaker assumes full responsibility - while the implicit ones depend more on the hearer's interpretation (Ducrot, 1987).

Regarding our field notes, we did not see any meaning in using DA because the expression in which interdiscourse manifests itself does not refer to the locus under study, but rather to the academic contextual insertion of the investigator who takes down the notes and is outside of the focus in question. Therefore, we decided to treat these data through content analysis, according to the thematic analysis approach, in which the data are organized into themes, seeking patterns of meanings, to be separated and categorized (Bardin, 1977; Bogdan \& Biklen, 1994).

The data analyzed were obtained from a group of subjects defined by the criterion of the time the people frequent the market, either as a customer, seller or supplier, with focus on the sale of fruits and vegetables. The initial group consisted of five merchants. The final group was expanded by the snowball technique, in which the previous interviewee referred us to the next ones (Bogdan \& Biklen, 
1994), and was defined by the saturation criterion (recurrence of information), constituted in the following way: 24 owners of stalls/shops at the market (5 produce merchants, 5 former produce merchants and 14 other merchants of varied items); 5 suppliers (3 of produce); 9 customers; 2 representatives of associations; 11 employees (4 of produce merchants and 7 of other types of merchants); and 3 security guards.

Of these, three merchants were chosen for an in-depth study of their lives in relation to the market. Each of them represent different movements, but with overlaps regarding their insertion in the historical context of the market and produce selling: (a) one man who migrated from a small town in the 1960s at the age of 14 and started out as a produce peddler in the area around the market and later acquired a stall inside the main building where he sold fruit and vegetables before selling it to another merchant and buying his own shop (around the market), which he has now built into a chain of grocery stores; (b) a man who was born and raised in the market, who started out at the age of seven in the 1960s as a peddler within the market, then took part in the invasion of the square facing the market in the 70s, where he operates his own stall today, besides renting a small area across from the fish market's area, both of which concentrate fruit and vegetable merchants; (c) a merchant who started in the 1980s as a supplier of produce to the market, and took over a stand in the invaded square as settlement of a debt owed to him, where he works today, and who was the first president of the Stand Owners Association that was created in the early 90s.

\section{The VR Market}

Originally opened in 1928, the VR took on its current configuration in the 1970s. It is centered around three large warehouse structures in which independent merchants own or rent small shops and stalls. These were originally built to sell fruit and vegetables, but today handcrafts are the predominant goods there. Around these structures, there are a variety of small stores, a structure for a fish market and a square that was invaded in the 1970s by peddlers, who set up stands there.

The large structures and other areas are separated by streets through which shoppers circulate. In these streets, in recent decades, customers, police, municipal inspectors, politicians, merchants and peddlers have developed ambiguous relationships of friendship/hostility and support/suppression due to the search for space to sell produce. In this context these actors, through their practices, have dealt with various matters at various times, such as fires, urban violence and financial crises.

In this way, commerce in fruit and vegetables predominated for many years. But in 1974, the wholesaling of fruit and vegetables was transferred to CEASA in another municipality. This caused a decline in the sale of these products at the market, aggravated by competition from supermarkets and specialized stores, spread throughout the city. Currently, the merchants who specialize in fruits and vegetables at the market are concentrated in a series of small portable stands set up across from the fish market structure, in one large store, and in some of small stalls around the square.

\section{Strategy as a Social Practice in Selling Produce at VR}

The analysis of the data revealed social constructs in which there is a dual movement in the everyday activities of strategizing: one in the direction of maintenance and the other in the direction of change of directions and in the practices themselves. Tables 1,2 and 3 summarize the analysis of the data and the movements mentioned during the analysis, in an attempt to understand the produce merchants' strategizing at the VR Market.

The directions highlighted in the analysis revolve around two thematas: family/survival/work; and the public/private set. At the macro social level, family/survival/work appeared related to the 
influence of the social inclusion of the subjects' parents or grandparents in the lower class of society. All the research subjects mentioned the difficulties with hunger and homelessness that their parents or grandparents had been subjected to because of poverty, which forced everyone to start working at an early age. Poverty was introduced almost as a concrete entity which at the macro level has influenced the past and propelled toward the future. This drive involves the objectification of labor as a matter of the family and its survival due to poverty and the need to deal with it escape from it.

Within this logic, poverty's influence is part of a distant past and is alive in the present, while the subject needs to deal with it by working together with his family. Accordingly, as shown in Table 1 , practices related to the hard work shared with their children and the family as a whole are highlighted, as well as concerns over how to manage the trade in which everyone works.

Along with the macro social level, the public/private factor appeared, associated with a recent past experienced by the subjects since they started to work at the market. Table 3 displays practices concerning the role of the government at the in a local, state and federal level as an entity that directly influences either to harm or help them, and this has broad implications for what happens in their routine. Among these implications were mentioned laws and other rules, such as the code of public attitudes and the way public resources are managed.

One example is the city's decision to build on its own ground new stalls for traders with public funds, in an area where there is little foot traffic. This is the private use of public resources since it will be used by a small group of traders. However, they themselves were against this mandatory transfer since they claimed that there was more foot traffic where they were before. Therefore, at first, they accepted the imposed change but later used their own material of the new stalls to return to where they used to work.

Within the private aspect of this duo, beside the use of public resources, the macro influence of what the subjects called major economic groups or big businessmen was highlighted, a reference to the supermarkets and their networks. For the subjects, the influence of this logic of large-scale trade which has intensified in the city over the last thirty years has imposed on them a new market logic in which they cannot compete without changing their traditional practices. The subjects associate a great deal of this influence with the changes in the choice of what to sell and how to sell it today. This involves the practices, as shown in Table 2, which indicates movements seeking a distance of focus adopted by these large-scale trades either through the sale of different products, a direction for opportunities or guidance to specific consumers.

Moving away from the macrosocial level, and moving towards the microsocial, the researches' subjects highlighted a series of practices with mutual influences, in a bricolage in which they are mutually composed and recomposed. There is also a link with the macrosocial level to the extent that these practices also introduced relationships with two thematas, hightlighted when it was established around three social representations of the research's subjects. (a) a social representation of the seller at Vila Rubim; (b) social representation of Vila Rubim and (c) social representation of the changes in the market at Vila Rubim.

Each of these representations is expressed with linked to the different hegemonic and emancipated dimensions. These dimensions and social practices are related and shown in Tables 1, 2 and 3. In the analysis, it was not possible to identify clear expressions of the controversial dimension of these social representations. To understand the reason for this absence, we need to recall that the basic distinction between the controversial and emancipated dimension is the fact that the former articulates its differences in relation to the others through an open, explicit conflict, aiming to subjugate the others. In VR's case, even when the subjects of the research are revealed through something, supposedly, antagonistic, involving practices in an explicit opposition, they pointed to the link between other constructions which prevailed and allowed the maintenance of this difference In other words, what the research should show from the controversial dimension came about from the emancipated dimension. 
One example is the question of the invasion of a public area which was vacant in front of the market, by peddlers who worked at the VR produce market. For the group who owned shops in the market, this should be solved because it was unfair competition against those who paid taxes. The invaders, on the other hand, defended their right to work.

The development expected in this case, was a manifestation of a controversial dimension in an open conflict between two opposing viewpoints. However, in the case of an explicit opposition that simply legitimized the expulsion of the invaders, the manifestations of the opposition to the invasion were linked to the necessity for public institutions to guarantee the right of these men to work by using their own resources, albeit without interfering or allowing unfair competition with those who were already legally working in those institutions. Therefore, something had to be done, even if it meant the expulsion of the invaders.

In turn, the invaders also demanded that the public institutions respect their right to work and that resources be used in their favor. In this perspective, the removal in the area was one more action among many others. Indeed, there were public institutional practices to this end, against which the invaders resisted. Their rights prevailed and the local government registered them and began to coordinate their operations, in the same way that the tenants of the stores are recognized and coordinated.

In this case, it was observed that the practices related to the attempts to expel the merchants were part of a broader emancipated dimension than just a controversial decision whether to expel the invaders. Even when this controversy arose, it did not take shape as a controversial dimension of social representations between two groups because the broad consensus within the group of tenants were not regarding the removal. This came about from a specific action among many other expressions which were highlighted by two sets of emancipated dimensions: (a) the social representation of the typical merchant whose hegemonic dimension is devotion to his work, which links the emancipated dimensions of the family, personal application and personal relationships (Table 1); (b) the social representations of the changes in the VR Market, whose hegemonic dimension is demands from and on public institutions, of the privatization of public areas and the emancipated dimension of competitive pressures (Table 3).

In this context, pervaded by these structures, besides not having a consensus within the tenants' group regarding the removal of the invaders as a simple and unique alternative, they were of a like mind regarding their right to work and oblige the public institutions to guarantee this, in the same way that they should do so for themselves. Similarly, different group structures of the subjects were articulated around the hegemonic and emancipated dimension presented in Tables 1, 2 and 3.

The tables show the links highlighted in data processing to the extent that it sought to understand the strategy of the produce merchants in Vila Rubim's Market. Among them, the empirical investigation made it possible to identify nine everyday strategies legitimized around three established social representations, such as that undertaken by Certeau (1990), who identified a place of one's very one.

In the social representation of the typical merchant (Table 1) three everyday strategies were identified: concerning the family; selling; personal relationships. Each of these appeared to be linked with an emancipated aspect specific to the social representation, respectively: emancipated dimension of the family; emancipated dimension of personal application; emancipated dimension of personal relationships. In turn, all these aspects are embedded in elements of a hegemonic view that in VR the typical merchant is a man devoted to work.

In links that have arisen in a similar manner but legitimized in different social constitutions, three everyday strategies related to the social representation of VR were identified (Table 2): the traditional commerce involving customers and suppliers and the specific features of the VR Market. Its expression is linked with an emancipated view of this social representation, respectively: emancipated dimension of the continuity of the commerce; emancipated dimension in the everyday activities 
involving customers; emancipated dimension of the match between the media efforts of the large stores, chicken and fish sellers. These views are embedded in the elements of the hegemonic aspect that VR is a traditional commercial venue in Vitória.

The last set of strategies highlighted in data processing appeared in accordance with the social representation of the changes in the VR Market (Table 3). The three everyday legitimized strategies were those of formal relationships; privatized space and the laws of the market. They were expressed as related, respectively, with the emancipated views referred to by the social representation: emancipated dimension of the demands from and on public institutions; emancipated dimension of the privatization of public space; emancipated dimension of competitive pressures. Together, these three views share elements of a hegemonic aspect that the changes in the VR Market are a consequence of the everyday events reflected in demands from and on the government and merchants.

In Tables 1, 2 and 3 the practices in the flows include structures inserted in the homonymous strategies, in the direction of determined interests and aspects strengthened by the same strategies. On the other hand, the practices included in the tactics, although they are legitimized in matters of such social representations, they do not necessarily enforce them, and could even oppose them, in an astute use of their own elements (Certeau, 1990).

For example, in Table 1, the strategy of personal relations, the merchant approaches a customer to make a sale for a neighboring merchant, passes the proceeds to that other merchant, thereby strengthening the personal ties between them, and consequently, the order that legitimizes this practice. But the same merchant can approach a customer as if he were making a sale for the other merchant, check that he is not being observed, and sell on his own behalf, in the tactic for personal relations. The possibility and the act of approaching the neighboring merchant's customer is the link that joins the homonymous strategy and tactic, but the process in each of them has different implications (strengthening or transgressing the established order) and develops in different and dynamic ways. 
Table 1

\section{Summary of the Social Practices Articulated Around the Social Representation of the Typical Merchant}

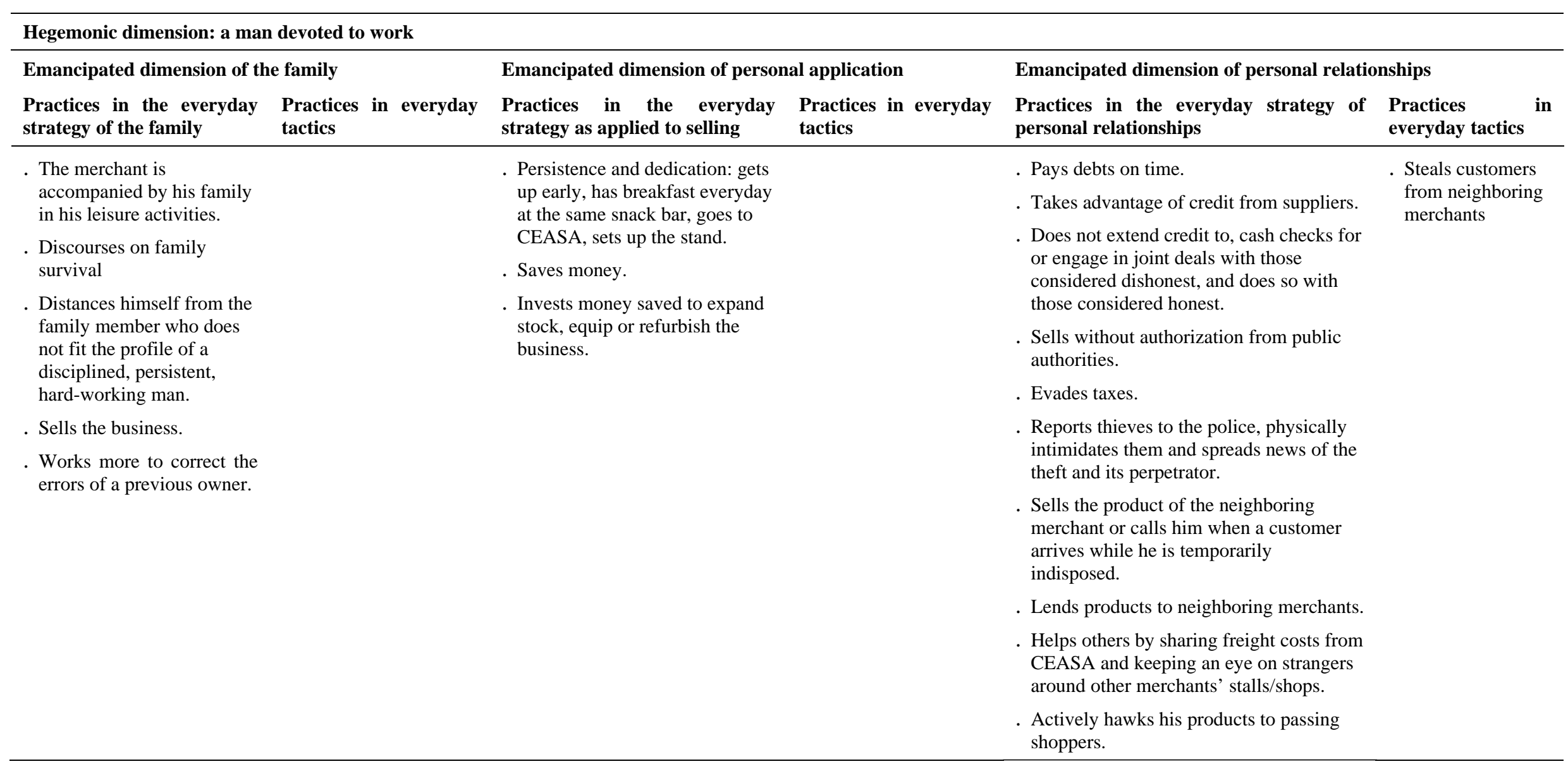

Note. Source: Study data 
Table 2

\section{Summary of the Social Practices Articulated Around the Social Representation of VR}

\begin{tabular}{|c|c|c|c|c|c|}
\hline \multicolumn{6}{|c|}{ Hegemonic dimension: a traditional commercial venue in Vitória } \\
\hline \multicolumn{2}{|c|}{ Emancipated dimension of the continuity of the commerce } & \multicolumn{2}{|c|}{$\begin{array}{l}\text { Emancipated dimension of the everyday activities involving } \\
\text { customers }\end{array}$} & \multicolumn{2}{|c|}{$\begin{array}{l}\text { Emancipated dimension of the match between the } \\
\text { media efforts of the big stores and chicken and } \\
\text { fish sellers }\end{array}$} \\
\hline $\begin{array}{l}\text { Practices in the everyday strategy } \\
\text { of the traditional commerce of the } \\
\text { respondent }\end{array}$ & $\begin{array}{l}\text { Practices in everyday } \\
\text { tactics }\end{array}$ & $\begin{array}{l}\text { Practices in everyday strategy involving } \\
\text { customers and suppliers }\end{array}$ & $\begin{array}{l}\text { Practices in } \\
\text { everyday tactics }\end{array}$ & $\begin{array}{l}\text { Practices in the everyday } \\
\text { strategy regarding the specific } \\
\text { features of VR Market }\end{array}$ & $\begin{array}{l}\text { Practices in } \\
\text { everyday tactics }\end{array}$ \\
\hline $\begin{array}{l}\text { Puts family members and } \\
\text { employees considered as such to } \\
\text { run the business and monitors } \\
\text { their daily tasks. } \\
\text {. Transfers the business, with } \\
\text { customers included. } \\
\text {. Gives family members financial } \\
\text { support, access to know-how and } \\
\text { network of contacts. } \\
\text {. Continues in the family business } \\
\text { or open your own. }\end{array}$ & $\begin{array}{l}\text { Does not allow his kids } \\
\text { follow his footsteps. } \\
\text {. Requires kids to study. } \\
\text {. Discourage older kids from } \\
\text { hanging around and } \\
\text { encourage them to find } \\
\text { better jobs. } \\
\text {. Allow kids to work, but } \\
\text { without interfering in their } \\
\text { studies. } \\
\text {. Use network of } \\
\text { relationships to find formal } \\
\text { jobs for kids. }\end{array}$ & $\begin{array}{l}\text { Keeps a large variety of items for sale. } \\
\text { Chooses the variety, quality and price of the } \\
\text { products to be purchased according to the } \\
\text { customer. } \\
\text {. Observes what the customer wants to buy. } \\
\text {. Deals with the supplier personally to build } \\
\text { loyalty. } \\
\text { Extends credit to those he trusts and cash only } \\
\text { business to those he distrusts. } \\
\text { Offers innovation or novelty as part of the } \\
\text { tradition of variety. } \\
\text { Seeks products with characteristics or prices } \\
\text { that few can match. } \\
\text { Yields exclusivity and supply products to his } \\
\text { friends. } \\
\text { Fills the buckets with fruit and vegetables to } \\
\text { sell more quickly when they begin to go off. . } \\
\text { Encourages customer loyalty with dialog, } \\
\text { freebies and selling on credit. } \\
\text { Helps others by sharing freight costs from } \\
\text { CEASA and making it possible to purchase a } \\
\text { wider variety of products. }\end{array}$ & & $\begin{array}{l}\text { Positions himself near the fish } \\
\text { market stall to sell produce. } \\
\text {. Increases stock of produce } \\
\text { when the demand and } \\
\text { consumption of fish and } \\
\text { chicken is greatest. } \\
\text {. Benefits from customers } \\
\text { attracted by the media } \\
\text { investments of supermarkets. }\end{array}$ & \\
\hline
\end{tabular}

Note. Source: Study data 
Table 3

\section{Summary of the social practices articulated around the Social representation of the changes in the VR Market}

\begin{tabular}{|c|c|c|c|c|c|}
\hline \multicolumn{6}{|c|}{ Hegemonic dimension: a consequence of everyday events reflected in demands from and on the government and merchants } \\
\hline \multicolumn{2}{|c|}{ Emancipated dimension of the demands from and on public institutions } & \multicolumn{2}{|c|}{$\begin{array}{l}\text { Emancipated dimension of the } \\
\text { privatization of public space }\end{array}$} & \multicolumn{2}{|l|}{ Emancipated dimension of competitive pressures } \\
\hline $\begin{array}{l}\text { Practices in the everyday } \\
\text { strategy of formal relationships }\end{array}$ & Practices in everyday tactics & $\begin{array}{l}\text { Practices in the } \\
\text { everyday strategy } \\
\text { of privatized space }\end{array}$ & $\begin{array}{l}\text { Practices in } \\
\text { everyday tactics }\end{array}$ & $\begin{array}{l}\text { Practices in the everyday strategy of the laws } \\
\text { of the market }\end{array}$ & $\begin{array}{l}\text { Practices in } \\
\text { everyday tactics }\end{array}$ \\
\hline $\begin{array}{l}\text { Hold meetings at the association. } \\
\text { Elect a president for the } \\
\text { association. } \\
\text { Pay the association's monthly } \\
\text { fees. } \\
\text { Invest the association's funds in } \\
\text { infrastructure, enrollment drives } \\
\text { and partnership arrangements. } \\
\text { Maintain interaction with public } \\
\text { institutions. } \\
\text { Argue that the products at the } \\
\text { street booths and stands do not } \\
\text { pay taxes. } \\
\text { Help and be helped by paying } \\
\text { the freight cost and making } \\
\text { business feasible in the face of } \\
\text { difficulties imposed by public } \\
\text { institutions. } \\
\text { Go to the booths offered and } \\
\text { built by the government. } \\
\text { Accept the offer to use public } \\
\text { funding. }\end{array}$ & $\begin{array}{l}\text { Expose the failings of public institutions } \\
\text { in the media to pressure them. } \\
\text { Set up booths to work wherever } \\
\text { necessary, even when against public } \\
\text { institutions. } \\
\text {. Articulate with politicians, scheduling. } \\
\text { meetings with them to air ideas, hand out } \\
\text { flyers, put up posters and monitor their } \\
\text { actions and explain to them what they } \\
\text { want in opposition to current demands } \\
\text { from public institutions } \\
\text {. Publicize the theme of unemployment to } \\
\text { oppose public institutions. } \\
\text {. Articulate with political actors through } \\
\text { personal relationships to oppose public } \\
\text { institutions. } \\
\text {. Confront inspectors from public } \\
\text { institutions violently. } \\
\text {. Replace violence with dialog with public } \\
\text { institutions and their representatives. } \\
\text { Yield to or obey the inspector } \\
\text { temporarily, and then go back to what } \\
\text { they were doing beforehand. }\end{array}$ & $\begin{array}{l}\text { Define the group } \\
\text { of invaders before } \\
\text { they invade. } \\
\text {. Enforce the rules, } \\
\text { even with } \\
\text { violence. }\end{array}$ & $\begin{array}{l}\text { Plan the retaking } \\
\text { of the public space } \\
\text { from the city } \\
\text { government } \\
\text { Be patient and } \\
\text { slowly change } \\
\text { what it is } \\
\text { prohibited to } \\
\text { change. }\end{array}$ & $\begin{array}{l}\text {. Stop selling what is not profitable. } \\
\text {. Constantly analyze the commerce that is not } \\
\text { functional. } \\
\text {. Start working with other products. } \\
\text {. Sell the shop. } \\
\text {. Know how to buy inventory, taking advantage } \\
\text { of prices at CEASA by arriving early, entering } \\
\text { beforehand as a delivery man and bargaining. } \\
\text {. Buy products according to the target customers. } \\
\text {. Buy fresher products to serve the target } \\
\text { customers and so they will stay fresh longer. } \\
\text {. Vary the quantity of produce in the buckets } \\
\text { instead of varying the price. } \\
\text {. Reduce the quantity of fruit and vegetables } \\
\text { when they are fresh, recover capital invested } \\
\text { and then increase the quantity in the buckets } \\
\text { until everything is sold before it spoils. } \\
\text {. Purchase a part of the fruit and vegetables } \\
\text { with better quality and a higher prices and in a } \\
\text { greater variety, to take up more space. } \\
\text {. Expand their space to grow, earn more, } \\
\text { expand space and so on. } \\
\text {. Always improve the shop. }\end{array}$ & $\begin{array}{l}\text { Expand your } \\
\text { space only to } \\
\text { survive. }\end{array}$ \\
\hline
\end{tabular}

Note. Source: Study data 
In the tables, each practice is part of one or two movements (maintenance and change) in relation to the contextual insertion of the subjects and the SR constructed by them, exposing the configuration of strategizing in terms of practices and meanings that flow through it.

In relation to the contextual insertion in the SR and the emancipated dimension that were used as a reference in the analysis and are reproduced in the tables, the everyday practices classified as tactics are based on the movements in the direction of the mentioned change of meanings, with or without maintenance of the practices. In contrast, the everyday practices classified as strategy are based on movements for the maintenance of meanings, also with or without maintenance of practices. In other words, the changes in practices involved in the social constructs of the subjects do not necessarily mean changes in the meanings inserted in these social constructs because the contrary also occurs: the practices change around earlier meanings, reinforcing them.

This was observed based on the proposed conceptual scheme, when in the case under study, the strategy making of the produce merchants was articulated around the thematas family/survival/work and public/private. These elements, at the same time, appear in hegemonic form, lead to specific constructs, exposed from the analysis of the set of emancipated dimensions of the SR anchored in those thematas. From this organization it was possible to indicate two sets of practices: those inserted in strategy and those inserted in everyday tactics.

The insertion of a practice in one or the other set was in relation to the social reference assumed, whether involving the social group (produce merchants at VR Market), or involving a cross section of their share (the emancipated dimensions in question). An aspect to stress, observed throughout the analysis and evident in the above tables, is that in this process some practices are positioned over time as everyday tactics and as everyday strategy.

By summarizing the produce merchants' practices in the tables, it was possible to observe these dual insertions, an adequate condition to illustrate the potential of the proposal for investigation based on the conceptual scheme advocated in this article. It is to offer space for social dynamism that one can observe the insertion of the practices in this dynamism, in which even when a practice remains the same, it can be permeated with different meanings at the same time or over time. In other words, the practice can involve anything from a simple reproduction of previous constructs, positioned in the space of a proper in which a determined established order must be maintained as it is to (without necessarily changing the concrete manifestations of the practice itself) a condition that transgresses this space, this order, and demarcates a singular space.

This occurs in the case of the practices involving political articulations, either aimed at opposition to formal demands or to fit within this order and benefit from it. More specifically, the ambiguity of social practices can be illustrated by focusing on a specific practice: that of expanding your space (Table 3), demarcated in the emancipated dimension of competitive pressures in the social representation of the changes at the VR Market. In relation to this dimension and the produce merchants' group of subjects, this practice is positioned in the space of the proper when articulated around the idea of market growth, and in a transgression space of the other when articulated around the idea of survival. Using simplistic logic, it could be conceived that the definition of one or the other insertion would hinge on the result attained or desired from this practice. But according to the conceptual scheme proposed, the result is permeated by the social context; it is not isolated. The very definition that it is a result of growth or survival only exists based on social constructs that delimit one or the other.

The demarcation of the meanings of the practices is based on the analysis, without which there is no reference. An example is to know what growth is and what survival is, since both can entail the same practice, that is, the same concrete evidence for the observer. In the conceptual table, this demarcation of meanings occurs through the SR which is inserted in the privileged condition of delimiting the place of the proper of establishing orders. In this sense, in the example, the emancipated dimension of the competitive pressures in the social representation in which the practice is articulated offers the basis for analysis. In this analysis, the successful produce merchant, cited in various 
fragments, is successful because he has grown. Thus, in this contextual insertion, the practice of expanding your space is positioned in the space of the proper and reinforces it. Nevertheless, in the conceptual scheme proposed, the tactic is not subordinated to these representations, nor to the strategy. In fact, to a certain extent, it is the contrary.

In using one of the elements of that place - in the case, the practice of expanding your space, but associated with the sense of survival - the very social representation in question is altered by the practice. If beforehand it reinforced, now it is associated with a new meaning, so that the emancipated dimension changes together with other constructs that attack. In this fashion, a new emancipated dimension can arise, a new place of a proper where perhaps to survive is to be successful, and expand your space to survive is a strategy delimited in this place.

This latter movement, in the case investigated, was not evidenced in the practice to expand your space, but it did involve another practice identified, that of violence (Table 3) on the part of the stall merchants. Beforehand, violence was a tactic, since these sellers, then itinerant peddlers (without a permanent stand or table to sell from, hence, precarious from a legal standpoint) confronted the hired security guards and police. Afterwards, the same sellers shifted from using violence as a strategy, acting as propers to keep order in the public square where their stands are set up. The social dynamic evidenced entails the maintenance of the practice through changes and innovations involving them.

On the other hand, new practices arise articulated in previous social constructs, such as the practice of helping to be helped, sharing the freight cost. In the analysis, it is articulated and associated simultaneously with three emancipated dimensions: personal relationships (Table 1); everyday activities involving customers (Table 2); and demands from and on public institutions (Table 3). In all these dimensions, the practice in question is part of an everyday strategy, converging with the order established by these dimensions and becoming legitimized therein. But as can be observed in the analysis, this practice only arose in the everyday life of VR when the wholesale marketing of fruit and vegetables was transferred from VR itself to CEASA, creating the need to share transport costs. This new practice changed the meanings inserted in the previous social constructs, presented in the emancipated dimensions. It reinforced them, uniting other practices, also previous, that articulated them, such as merchants lending money and merchandise to one another.

From the above, it can be seen that the strategy in selling produce at VR involves a social dynamism in which social constructs articulate in movements toward maintenance, change and emergence of practices and meanings that involve these constructs. In this movement, the changes in the concrete manifestations of these practices do not necessarily depend on changes in the meanings involving them, and vice versa. Therefore, a better understanding of this dynamism depends on a deeper socio-historical contextual insertion, which hinges on these meanings and the concrete manifestations of these practices, going beyond an isolated analysis of concrete manifestations and of the results that are desired or obtained, but one that includes these elements in being articulated by the research subjects in that social dynamism.

\section{Final Considerations}

In recalling the proposed objective it can be observed that the comparison of Tables 1, 2 and 3, employing the conceptual scheme adopted, reveals strategy as a social practice in the case under study. In their socio-historical process, the produce merchants at the VR Market articulate various flows inserted in wider and more specific organizational contexts, i.e., various everyday strategies and tactics.

Within the approach followed in this article, the denomination of strategies and practices is dynamic, relational and temporary because the focus is on the process that permeates each strategy and its articulations in the practices and meanings in each flow. In Tables 1, 2 and 3, each flow has its 
practices identified in the summarized analysis in one column, but it is only possible to understand the processes that involve the practices, in the strategizing, by resorting to the relational meanings of each practice. In the case of this article, these meanings were detailed in the analyses of the three SR that run through the everyday lives of the research subjects. Without this previous discussion, the table by itself would not make sense because it only presents isolated practices. This reinforces the argument that understanding strategy as social practice demands recognition of the social constructs that permeate such practices. This goes far beyond identifying concrete manifestations, but involves this identification since it is one more step to reach the other social constructs hinging on these manifestations.

In the conceptual scheme, these meanings permeate social practices in the articulations around the emancipated dimensions of the SR presented in the analysis. These meanings appear to be inseparable from the directions of the strategizing of the produce merchants of the VR Market. This does not mean that there is a simplistic cause and effect relationship between the meanings and strategizing, as one sense might indicate, or vice versa. We observed that the practices inserted in the research subjects' strategizing can remain the same in relation to their concrete manifestations, but be articulated in different ways, and new practices arise articulated in previous ways, as was observed in the sharing of expenses from CEASA for those inserted in the meaning of friend within the merchants' personal relationships.

These aspects evidenced in the empirical analysis legitimize the position that the conceptual model proposed permitted attaining the objective of this article around the following interpretation: the constitution of the merchants' strategies in the produce market in Vila Rubim in Vitória, ES, from 1970 to the present time occur in a dynamic way, involving simultaneous movements in the direction of maintenance and of change in meanings and strategizing, interrelated in everyday practices. In a process where the old practices gain new meanings and new practices are established related to the new or old meanings, establishing this way a dynamic in which the new and old are joined in an embedded manner.

The final contribution of this article is that the discussion developed herein should be applied and expanded. The development of this proposal certainly does not stop here; on the contrary, the intention is to spur discussion and incorporate knowledge from other researchers and groups interested in the development of the approach to strategy as a social practice.

\section{Received 19 August 2009; received in revised form 16 August 2010.}

\section{Note}

\footnotetext{
${ }^{1}$ This study was supported by grants from the CNPq and FAPEMIG.
}

\section{References}

Bakhtin, M. (1986). Speech genres and other late essays. Austin: University of Texas.

Bardin, L. (1977). Análise de conteúdo. Lisboa: Edições 70.

Barry, D., \& Elmes, M. (1997). Strategy retold: towards a narrative view of strategic discourse. Academy of Management Review, 22(2) 429-452. doi:10.2307/259329.

Bogdan, R. C., \& Biklen, S. K. (1994). Investigação qualitativa em educação. Porto: Porto Editora. 
Bourdieu, P. (1990). The logic of practice. Stanford: Stanford Univ. Press.

Certeau, M. de (1986). Heterologies. Minneapolis: University of Minnesota Press.

Certeau, M. de (1990). L'invention du quotidien: arts de faire. Paris: Gallimard.

Certeau, M. de, Giard, L., \& Mayol P. (1994). L'invention du quotidien: habiter, cusiner. Paris: Gallimard.

Clegg, S., Carter, C., \& Kornberger, M. A. (2004). Máquina estratégica: fundamentos epistemológicos e desenvolvimento em curso. Revista de Administração de Empresas, 44(4), 21-31.

Denzin, N. K., \& Lincoln, Y. S. (2006). Introdução. In N. K. Denzin \& Y. S. Lincoln (Orgs.), O planejamento da pesquisa qualitativa: teorias e abordagens (pp. 15-41). Porto Alegre: Artmed.

Ducrot, O. (1987). O dizer e o dito. Campinas: Pontes.

Ezzamel, M., \& Willmott, H. (2004). Rethinking strategy: contemporary perspectives and debates. European Management Review, 1(1), 43-48.

Fiorin, J. L. (2003). Linguagem e ideologia (7th ed.). São Paulo: Ática.

Foucault, M. (1987). Surveiller et punir. Paris: Éditions Gallimard.

Giddens, A. (1984). The constitution of society. Los Angeles: University of California.

Jarzabkowski, P. (2005). Strategy as practice. London: Sage.

Jarzabkowski, P., \& Wilson, D. C. (2002). Top teams and strategy in a UK university. Journal of Management Studies, 39(3), 355-381. doi: 10.1111/1467-6486.00296

Jodelet, D. (1989). Représentations sociales. In D. Jodelet (Ed.), Les Représentations Sociales (pp. 3162). Paris: PUF.

Johnson, G., Melin, L., \& Whittington, R. (2003). Guest editors' introduction: micro strategy and strategizing: towards an activity-based view. Journal of Management Studies, 40(1), 3-22. doi:10.1111/1467-6486.t01-2-00002

Liu, L. (2003). Sensitising concept, themata and shareness: a dialogical perspective of social representations. Journal for the Theory of Social Behaviour, 34(3), 249-264. doi: 10.1111/j.0021-8308.2004.00247.x

Liu, L. (2006). Quality of life as a social representation in China: a qualitative study. Social Indicators Research, 75(2), 217-240. doi 10.1007/s11205-004-3198-z

Marková, I. (2000). Amédée or how to get rid of it: social representations from a dialogical perspective. Culture \& Psychology, 6(4), 419-460. doi: 10.1177/1354067X0064002

Mintzberg, H. (1978). Patterns in strategy formation. Management Science, 24(9), 934-948. doi : 10.1287/mnsc.24.9.934

Moscovici, S. (1961). La psychanalyse: son image et son public. Paris: Presses Univ. de France.

Moscovici, S. (1984). The phenomenon of social representations. In R. Farr \& S. Moscovici (Eds.), Social Representations (pp. 3-69). Cambridge: Cambridge University Press.

Moscovici, S. (1993). Introductory address. Papers on Social Representations, 2(3), 160-170.

Moscovici, S., \& Marková, I. (1998). Presenting social representations: a conversation. Culture \& 
Psychology, 4(3), 371-410. doi: 10.1177/1354067X9800400305

Moscovici, S., \& Vignaux, G. (1994). Le concept de thêmata. In C. Guimelli (Ed.), Strutures et transformations des representations sociales (pp. 25-72). Neuchâtel: Delachaux et Nieslé.

Mumby, D. K., \& Stohl, C. (1991). Power and discourse in organization studies: absence and the dialectic of control. Discourse \& Society, 2(3), 313-332. doi: 10.1177/0957926591002003004

Pettigrew, A. (1977). Strategy formulation as a political process. International Studies of Management \& Organization, 7(2), 78-87.

Regnér, P. (2003). Strategy creation in the periphery: inductive versus deductive strategy making. Journal of Management Studies, 40(1), 57-82. doi: 10.1111/1467-6486.t01-1-00004

Rosa, A. (2006). The 'boomerang' effect of radicalism in discursive psychology: a critical overview of the controversy with the social representations theory. Journal for the Theory of Social Behaviour, 36(2), 161-201. doi: 10.1111/j.1468-5914.2006.00302.x

Samra-Fredericks, D. (2003). Strategizing as lived experience and strategists' everyday efforts to shape strategic direction. Journal of Management Studies, 40(1), 141-174. doi: 10.1111/14676486.t01-1-00007

Vergès, P. (1989). Représentations sociales de l'économie. In D. Jodelet (Ed.), Les représentations sociales (pp. 203-209). Paris: PUF.

Watson, T. J. (1995). Rhetoric, discourse and argument in organizational sense making: a reflexive tale. Organization Studies, 16(5), 805-822. doi: 10.1177/017084069501600503

Whittington, R. (1996). Strategy as practice. Long Range Planning, 29(5), 731-735. doi:10.1016/00246301(96)00068-4

Whittington, R. (2003). The work of strategizing and organizing: for a practice perspective. Strategic Organization, 1(1), 117-125. doi: 10.1177/147612700311006

Wilson, D., \& Jarzabkowski, P. (2004). Thinking and acting strategically: new challenges for interrogating strategy. European Manage Management Review, 1(1), 14-20. doi:10.1057/palgrave.emr.1500008

Yin, R. K. (1989). Case study research: design and methods. Newbury Park, CA: Sage Publications. 